\title{
Fluoride concentration in Peruvian salts and the standardization of analysis with specific electrode by the direct method
}

Jaime Aparecido Cury ${ }^{1}$, Karla Irina Walsh², Waldomiro Vieira $^{3}$, Jennifer Ricaldi ${ }^{4}$

1 Professor of Biochemistry. Department of Physiological Sciences, Piracicaba Dental School, University of Campinas, Piracicaba, SP, Brazil. jcury@unicamp.br Tel. 1921065302

${ }^{2} \mathrm{MSc}$. in Cariology. Department of Physiological Sciences, Piracicaba Dental School, University of Campinas, Piracicaba, SP, Brazil. kwalsh31@hotmail.com Tel. 50583204966

${ }^{3}$ Technical assistant. Department of Physiological Sciences, Piracicaba Dental School, University of Campinas, Piracicaba, SP, Brazil. wvfilho@unicamp.br Tel. 1921065303

${ }^{4}$ Assistant Professor at Social Dentistry Department at Universidad Peruana Cayetano Heredia, Lima-Perú. Jenniferricaldi@gmail.com Tel. +1 2069603760

Corresponding author: Prof. Jaime Aparecido Cury Piracicaba Dental School, PO box 52 13414-903, Piracicaba, SP, Brazil Tel. +55 192106 5303, Fax +55 19 21065302

e-mail: jcury@unicamp.br

Received: March 28, 2018

Accepted: April 23, 2018
According to the Peruvian legislation, salt for human consumption should contain 200-250 mg F/ $\mathrm{kg}$, but there is limited data showing whether this requirement is being accomplished. Aim: In this pilot study, we evaluated the fluoride concentration in samples of salt marketed in Lima Peru, using a standardized protocol with ion-specific electrode by direct method (ISE). Methods: Seven $1 \mathrm{~kg}$ salt packages of four brands were purchased in two supermarkets of Lima. Six aliquots of each package were weighed and dissolved in the proportion of $0.025 \mathrm{~g} / \mathrm{mL}$ of water. Duplicates of $1.0 \mathrm{~mL}$ of these solutions were mixed with $1.0 \mathrm{~mL}$ of TISAB II and fluoride concentration was determined with ISE calibrated with standards fluoride solutions ranging from 0.25 to $16.0 \mu \mathrm{g} \mathrm{F} /$ $\mathrm{mL}$. The ionic strength of the standards was adjusted with $\mathrm{p}$.a $\mathrm{NaCL}(25 \mathrm{mg} / \mathrm{mL})$. In addition, triplicates of $15 \mathrm{~g}$ of each salt package were fractionated in a set of sieves (0.590 to 0.177 $\mathrm{mm}$ ) to determine the homogeneity of fluoride concentration in salt. Results: In four packages the mean fluoride (mean $\pm S D, n=6$ ) concentration ( $\mathrm{mg} \mathrm{F} / \mathrm{kg}$ ) was in agreement to the Peruvian regulation $(214.5 \pm 10.4 ; 221.8 \pm 14.3 ; 226.9 \pm 19.1$ and $237.2 \pm 52.0 \mathrm{mg} \mathrm{F} / \mathrm{kg}$ ), but in 3 packages it was lower $(145.2 \pm 7.9 ; 145.7 \pm 23.3$ and $158.4 \pm 20.6 \mathrm{mg} \mathrm{F} / \mathrm{kg}$ ). Variability in fluoride concentration was observed within the same brand and among brands. Also, the fluoride concentration was not homogeneous in none of the salt samples, ranging from 72.0 to $1449.7 \mathrm{mg} \mathrm{F} / \mathrm{kg}$. Conclusion: The findings suggest that the manufacturing and sanitary surveillance of fluoridated salt in Peru should be improved.

Keywords: Fluoridation. Dental caries. Ion-Selective Electrodes 


\section{INTRODUCTION}

Oral health approaches based on the safe use of fluorides have contributed worldwide to the reduction of dental caries ${ }^{1}$. Among the ways of use of fluoride, the community based is considered the one with greater coverage, allowing the benefit of all social classes. Salt fluoridation is a community based strategy to prevent tooth decay and it has been recommended as an effective alternative to water fluoridation ${ }^{2-5}$. In addition, salt fluoridation has been implemented in several Latin American countries, reaching nearly 200 million people $e^{6,7}$.

On the other hand, an adequate fluoride surveillance system is required to guarantee that any program of fluoride use reaches the maximum anticaries benefits with the minimal risk to develop undesirable side effects, such as dental fluorosis ${ }^{8}$. One of the advantages of salt fluoridation compared to water would be the facility to monitor the fluoride concentration, because in any country the number of salt producers to be monitored is very smaller than the number of water treatment plants. Despite this advantage, fluoride concentrations below or above those established by local legislations have been found in salt brands sold in El Salvador, México, Colombia and Peru"-15.

In Peru, the fluoridated salt program was set in $1984^{16}$ and the fluoride concentration in salt for human consumption should be from 200 to $250 \mathrm{mg} \mathrm{F} / \mathrm{kg}^{17}$. Official data about the fluoride concentration in Peruvian salts have not been reported and searching the literature it was found only one evaluation carried out 12 years ago ${ }^{15}$. Ten brands of salt were purchased in 34 markets from the province of Trujillo, north coast of Peru. However, only one brand was fluoridated and the concentration found was below the legislation (152 ppm F).

Considering the scarce and limited data found, the aim of this study was to report updated findings about the fluoride concentration in salts brands sold in Peru.

\section{MATERIAL AND METHODS}

This exploratory in vitro study, blind regarding the analyst, determined the fluoride concentration in four fluoridated salt brands of human consumption found in Lima, Peru. Seven $1 \mathrm{~kg}$ packages were purchased in 2013, in two supermarkets of Lima city. It was recorded the producer, batch, validity, type of granulation, ingredients and fluoride concentration declared on the package label (Table 1).

\section{Standardization of the sample salt weight taken for analysis}

The fluoride concentration in salt could be influenced by the amount of salt sample taken for analysis if the mixture of $\mathrm{NaCL}$ and the fluoride salt used is not homogeneous. Therefore, to obtain more accurate results, it was investigated which would be the weight of salt aliquots representative of the mean fluoride concentration in the salt package. For analysis, salt aliquots from 0.025 to $2.5 \mathrm{~g}( \pm 0.01)$ were dissolved in purified water at a ratio of 1:40 (w/v). Fluoride concentration was determined using ion-specific electrode (ISE) by the direct method and the concentration of $\mathrm{NaCL}$ in fluoride standard solutions was adjusted according to the sample ${ }^{18}$. The variation coef- 
Table 1. Producer, code for analysis, salt brands, batch and validity, granulation type, fluoride concentration and ingredients declared on the label

\begin{tabular}{|c|c|c|c|c|c|c|}
\hline Producer & Code & Salt brands & $\begin{array}{l}\text { Batch and } \\
\text { validity }\end{array}$ & $\begin{array}{c}\text { Type of } \\
\text { granulation }\end{array}$ & $\begin{array}{c}\text { Fluoride } \\
\text { concentration } \\
\text { declared } \\
(\mathrm{mg} \mathrm{F} / \mathrm{kg})\end{array}$ & Ingredients \\
\hline $\begin{array}{l}\text { QUIMPAC } \\
\text { S.A. }\end{array}$ & 1 & $\begin{array}{c}\text { Pura Sal } \\
\text { yodada cocina }\end{array}$ & $\begin{array}{c}\text { LT.LN } \\
\text { 10910131 FV } \\
\text { 091015_17:19_3 }\end{array}$ & fine & $200-250$ & $\begin{array}{c}\mathrm{KF}, \mathrm{KIO}_{3}, \mathrm{SiO}_{2} \\
(\max 1 \%)\end{array}$ \\
\hline Idem & 2 & $\begin{array}{c}\text { Pura Sal } \\
\text { yodada cocina }\end{array}$ & $\begin{array}{c}\text { LT.LN } 11 \\
\text { 210 131 FV } \\
\text { 121015_01:24_2 }\end{array}$ & fine & Idem & Idem \\
\hline Idem & 3 & $\begin{array}{l}\text { Em Sal yodada } \\
\text { cocina }\end{array}$ & $\begin{array}{c}\text { LT. } \\
\text { LN11109131 FV } \\
\text { 1109154_06:15_1 }\end{array}$ & fine & Idem & Idem \\
\hline Idem & 4 & $\begin{array}{l}\text { Em Sal yodada } \\
\text { cocina }\end{array}$ & $\begin{array}{c}\text { LT. LN } \\
\text { 12710131 FV. } \\
\text { 271015_02:38_1 }\end{array}$ & fine & Idem & Idem \\
\hline Idem & 5 & $\begin{array}{l}\text { Sal Extra } \\
\text { Refinada- } \\
\text { Marina }\end{array}$ & $\begin{array}{c}\text { LT.LN11310131 } \\
\text { FV } \\
\text { 131015_04:06_1 }\end{array}$ & refined & Idem & Idem \\
\hline Idem & 6 & $\begin{array}{c}\text { Sal Extra } \\
\text { Refinada- } \\
\text { Marina }\end{array}$ & $\begin{array}{c}\text { LT.LN127101311 } \\
\text { FV } \\
\text { 271015_04:18_3 }\end{array}$ & refined & Idem & Idem \\
\hline Idem & 7 & $\begin{array}{l}\text { Em Sal yodada } \\
\text { mesa }\end{array}$ & $\begin{array}{c}\text { P 16.09.13 V } \\
16.09 .1513: 47 \text { B2 }\end{array}$ & fine & Idem & Idem \\
\hline
\end{tabular}

ficient of the fluoride concentration in the salt samples weighing less than $2.5 \mathrm{~g}$ was high (up to $30 \%$ ), while in samples weighing around $2.5 \mathrm{~g}$ it was lower (10\%). Thus, salt aliquots with weight of around $2.5 \mathrm{~g}$ were taken for this study.

\section{Standardization of fluoride determination with ion selective electrode (ISE) by the direct method}

The analysis of the fluoride concentration with ISE by direct method is subjected to interferers ${ }^{19,20}$. Calcium-ferrocyanide, calcium carbonate, calcium triphosphate, magnesium oxide, magnesium hydroxide and magnesium carbonate are usually added to salt as anticaking agents ${ }^{21}$. $\mathrm{Ca}^{++}$and $\mathrm{Mg}^{++}$ions form complexes with fluoride that could interfere with the determination of fluoride in salt using ISE by the direct method ${ }^{22}$. Another problem is the ionic strength of the salt solutions prepared for analysis because it decreases the activity of the fluoride ion in solution. The interference of $\mathrm{Ca}^{++}$and $\mathrm{Mg}^{++}$could be controlled by the presence of chelating agents added in the buffer solution used for the analysis, such as CDTA presents in TISAB II (Total ionic strength adjustment buffer). The effect of the ionic strength could be controlled by preparing a very diluted salt solution for analysis. However, as described in the previous item, it is necessary to weigh a representative amount 
of salt to obtain a more accurate fluoride concentration in salt. Thus, the concentration of salt in the solution prepared may surpass the concentration of $\mathrm{NaCL}$ $(1.0 \mathrm{M})$ contained in the TISAB II buffer. This problem has been solved adding pure $\mathrm{NaCL}$ in the TISAB II buffer to prepare the fluoride standard solutions used in the calibration curve ${ }^{18}$, as is described further.

To test the effect of the ionic strength on the accuracy of the fluoride concentration determination, salt sample solutions from $0.5 \%$ to $20 \%(\mathrm{w} / \mathrm{v}$ ) were prepared. Fluoride concentration was determined using calibration curves made with standard fluoride solutions adjusted or not (raw data) with pure NaCL (Sigma Aldrich, Lot \# 70M027330V) according to the percentage of salt in the solution prepared for analysis.

Figure 1 shows fluoride concentration ( $\mathrm{mg} \mathrm{F} / \mathrm{kg}$ ) found in salt according to the amount of salt ( $\mathrm{g}$ ) dissolved in $100 \mathrm{~mL}$ of purified water, determined from calibration curves made with standard fluoride solutions not adjusted (raw data) or adjusted (data normalized) according to the percentage of $\mathrm{NaCL}$ in the samples. If the salt concentration in the standard solutions is not adjusted (below curve), the fluoride concentration is underestimated from $4 \%$ to $15 \%$. Also, the data shows that a more accurate fluoride concentration is obtained when salt is prepared at proportion of around $2 \mathrm{~g}$ of salt in $100 \mathrm{~mL}$ of water and the standard solutions are adjusted with pure NaCL. Below and above this weight, the concentration of fluoride is underestimated. Thus, a final proportion around $2.5 \mathrm{~g}$ of salt dissolved in $100 \mathrm{~mL}$ of purified water was used for the analysis of salt samples.

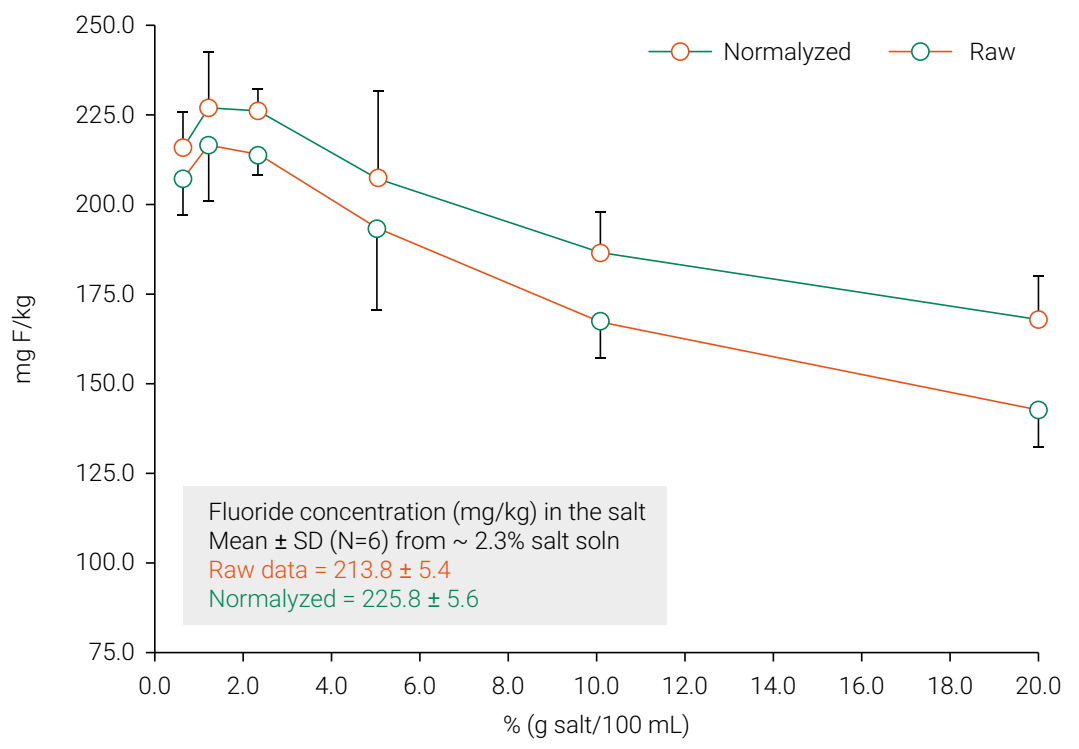

Figure 1. Concentration of fluoride found in salt (mg F/kg) according to the amount ( $\mathrm{g}$ ) of salt dissolved in $100 \mathrm{~mL}$ of purified water, determined from calibration curves made with standards fluoride solutions adjusted or not with p.a NaCL according to the \% of salt in the samples. 


\section{Salt sample harvest and preparation for analysis}

The salt packages were manually agitated for $2 \mathrm{~min}$ for homogenization. Six aliquots weighting $2.5 \mathrm{~g}( \pm 0.01)$ were harvested from the top of each package and dissolved in the proportion of $0.025 \mathrm{~g} / \mathrm{mL}$ of purified water. To each duplicate of $1 \mathrm{~mL}$ of the prepared solutions, $1 \mathrm{~mL}$ of TISAB II was added $(1: 1 ; \mathrm{v} / \mathrm{v})$. Fluoride analysis was carried out as is described further.

\section{Assessment of the fluoride concentration homogeneity in the salt package}

To determine the homogeneity of fluoride in the salt packages, triplicates of $15 \mathrm{~g}$ of each package were fractionated using a set of sieves (Telatest) with tyler of 28 $(0.59 \mathrm{~mm}), 35(0.42 \mathrm{~mm}), 60(0.250 \mathrm{~mm})$ and $80(0.177 \mathrm{~mm})$. After $1 \mathrm{~min}$ of manual agitation, the fractions of salt that passed through the 28-60 tyler as well as the retained in the tyler 80 (particles from $<0.177$ to $>0.590$ ) were collected and dissolved in the proportion of $0.025 \mathrm{~g} / \mathrm{mL}$ of purified water. Solutions were prepared as described before for fluoride determination.

\section{Fluoride analysis}

The fluoride concentration in the salt solutions was determined using ion-specific electrode (Orion 96-09, Thermo Scientific, Cambridge, MA, EUA) coupled to an ion analyzer (Orion Star A214; Thermo Scientific, EUA). This equipment was previously calibrated with standard fluoride solutions ranging from 0.25 to $16.0 \mu \mathrm{g} \mathrm{F} / \mathrm{mL}$, mixed in ratio $(1: 1 ; \mathrm{v} / \mathrm{v})$ with TISAB II added of $0.025 \mathrm{~g} \mathrm{NaCL}$ (p.a) $/ \mathrm{mL}^{18}$.

Microsoft Excel software was used to estimate by linear regression the relationship between the logarithm of the fluoride concentration in the standards and the $\mathrm{mV}$. The linear correlation coefficient was of 0.999 . The regression was used to determine the fluoride concentration in the samples and the average coefficient of variation for the duplicate analysis was of $1.3 \%$.

For the data analysis, it was calculated the mean $( \pm S D ; n=6)$ fluoride concentration in every package and the mean $( \pm S D ; n=3)$ and range of fluoride concentration in the fractionated samples of salt. The results were expressed in $\mathrm{mg} \mathrm{F} / \mathrm{kg}$ and compared with the range of fluoride concentration demanded by the Peruvian legislation.

\section{RESULTS}

Only 4 brands of fluoridated salt were found in two supermarkets of Lima, all from the same manufacturer, QUIMPAC, that is responsible for $60 \%$ of salt marketed in Peru. From 3 brands were purchased 2 packages, one in each supermarket, but one brand was found in only one supermarket. Seven salt packages from different batches were purchased and analyzed (Table 1).

Five out of the seven (71\%) salt samples analyzed were fine granulated and the remaining two $(29 \%)$ refined granulated. All the samples were iodized and had silicon dioxide (max $1 \%$ ) as the anticaking agent. The fluoride agent declared by the manufacturer in all the samples was KF and the final fluoride concentration declared was in the range of 200 to $250 \mathrm{mg} \mathrm{F} / \mathrm{kg}$. 
Results showed that the mean ( $\pm \mathrm{SD} ; \mathrm{n}=6$ ) of fluoride concentration ( $\mathrm{mg} \mathrm{F} / \mathrm{kg}$ ) of the salt samples ranged from 145.2 to $237.2 \mathrm{mg} \mathrm{F} / \mathrm{kg}$ (Table 2). In four packages, the fluoride concentration was according to the Peruvian legislation (salts code 2,4,6 and 7), but, in three of them (salts code 1,3 and 5) it was lower.

Table 2. Code, salt brands and mean ( $\pm S D ; n=6$ ) of fluoride concentration ( $m g ~ F / k g)$ found in the samples of salt

\begin{tabular}{lcc}
\hline Code & Salt brands & *mg F/kg \\
\hline 1 & PuraSal yodada cocina & $145.7 \pm 23.3$ \\
\hline 2 & PuraSal yodada cocina & $214.5 \pm 10.4$ \\
\hline 3 & emsal yodada cocina & $145.2 \pm 7.9$ \\
\hline 4 & emsal yodada cocina & $221.8 \pm 14.3$ \\
\hline 6 & Sal extra refinada-Marina & $158.4 \pm 20.6$ \\
\hline 7 & Sal extra refinada-Marina & $226.9 \pm 19.1$ \\
\hline
\end{tabular}

* Expected: 200-250 mg F/kg, according to Peruvian regulation

The fluoride concentration $( \pm S D ; n=3)$ found $(\mathrm{mg} \mathrm{F} / \mathrm{kg}$ ) in the fractionated samples of salt is shown in Table 3 . The concentration in the fractions of the salt code 2 was the most heterogeneous (from 116.2 to 1449.7), while in salts 3 and 5 it was the most homogeneous (from 164.6 to 221.3 and 164.6 to 221.3 , respectively).

Table 3. Mean ( \pm SD; $n=3$ ) of fluoride concentration $(\mathrm{mg} \mathrm{F} / \mathrm{kg})$ found in the fractions of the salt samples and the range found

\begin{tabular}{|c|c|c|c|c|c|c|c|}
\hline \multirow{2}{*}{ Code } & \multirow{2}{*}{ Salt Brands } & \multicolumn{5}{|c|}{ Particle size (mm) } & \multirow{2}{*}{ Range } \\
\hline & & $<0.177$ & $0.1770-250$ & $0.250-0.420$ & $0.420-0.590$ & $>0.590$ & \\
\hline 1 & $\begin{array}{l}\text { PuraSal yodada } \\
\text { cocina }\end{array}$ & $332.4 \pm 228.6$ & $181.6 \pm 32.2$ & $137.0 \pm 11.8$ & $98.6 \pm 27.9$ & $126.6 \pm 23.2$ & $98.6-332.4$ \\
\hline 2 & $\begin{array}{l}\text { PuraSal yodada } \\
\text { cocina }\end{array}$ & $125.6 \pm 11.0$ & $116.2 \pm 3.1$ & $202.5 \pm 65.3$ & $1449.7 \pm 1496.1$ & $271.0 \pm 12.4$ & $116.2-1449.7$ \\
\hline 3 & $\begin{array}{l}\text { emsal yodada } \\
\text { cocina }\end{array}$ & $115.1 \pm 19.0$ & $155.8 \pm 39.1$ & $127.1 \pm 46.3$ & $159.4 \pm 49.5$ & $167.5 \pm 14.3$ & $115.1-167.5$ \\
\hline 4 & $\begin{array}{l}\text { emsal yodada } \\
\text { cocina }\end{array}$ & $141.6 \pm 7.1$ & $72.0 \pm 16.5$ & $152.3 \pm 39.7$ & $420.9 \pm 25.9$ & $234.8 \pm 9.8$ & $72.0-420.9$ \\
\hline 5 & $\begin{array}{c}\text { Sal extra } \\
\text { refinada-Marina }\end{array}$ & $218.7 \pm 35.8$ & $221.3 \pm 65.4$ & $178.7 \pm 24.3$ & $164.6 \pm 14.4$ & $167.5 \pm 53.3$ & $164.6-221.3$ \\
\hline 6 & $\begin{array}{l}\text { Sal extra } \\
\text { refinada-Marina }\end{array}$ & $382.0 \pm 62.7$ & $297.3 \pm 91.7$ & $159.8 \pm 11.0$ & $120.9 \pm 12.6$ & $275.3 \pm 112.7$ & $120.9-382.0$ \\
\hline 7 & $\begin{array}{c}\text { emsal yodada } \\
\text { mesa }\end{array}$ & $375.2 \pm 28.6$ & $290.7 \pm 40.4$ & $211.4 \pm 10.7$ & $121.9 \pm 12.1$ & $93.7 \pm 13.6$ & $93.7-375.2$ \\
\hline
\end{tabular}

\section{DISCUSSION}

The monitoring of the fluoride concentration in salt is necessary to guarantee the maximum anticaries benefits with the minimal risk to develop unacceptable dental 
fluorosis in the population. To determine an accurate and precise fluoride concentration in salt is essential to have a valid methodology of analysis. Additionally, the analysis should be feasible to be conducted in any country where salt fluoridation programs were implemented.

Our findings showed that accurate fluoride concentration in salt was found when salt sample solutions were prepared at concentration of around $2.5 \%(\mathrm{w} / \mathrm{v})$ and the ionic strength of the fluoride standards were adjusted with pure NaCL (Fig 1). These results were obtained using ion specific electrode (ISE) by direct analysis but a publication has suggested that the determination of fluoride in salt using ISE should be made after microdifussion and not by the direct analysis ${ }^{19}$. However, according to this publication suggesting that microdifussion should be used ${ }^{19}$, fluoride concentration determined in the salt by the direct analysis was made from a 10\% salt solution and the ionic strength of the samples was not adjusted. As Fig 1 shows, if a salt sample solution is prepared at $10 \%$ and the electrode is calibrated without adjustment of the ionic strength, the fluoride concentration would be underestimated in $27 \%$, compared with the concentration found from analysis of $2.5 \%$ salt solution. It should be emphasized that even with the adjustment of the ionic strength, the fluoride concentration in the salt from analysis of a $10 \%$ solution would still be underestimated in $18 \%$ (Fig.1). In conclusion, to obtain accurate results is necessary to weigh an amount of salt that is representative of the fluoride concentration in the salt (at around $2.5 \mathrm{~g}$ ) which may be dissolved in the proportion of $0.025 \mathrm{~g} / \mathrm{mL}$ of water. Also, the ionic strength of the fluoride standards must be properly adjusted with $\mathrm{NaCL}$ chemically pure.

Regarding the results found and the surveillance system of the salt fluoridation program in Peru, the local legislation establishes that the adequate range of fluoride in salt for human consumption should be from 200 to $250 \mathrm{mg} \mathrm{F} / \mathrm{kg}^{17}$. Thus, fluoride concentration in salt below or above this range would not have a maximum anticaries benefit or would provoke unacceptable fluorosis, respectively. According to the findings (Tab 2), 57\% of the samples analyzed showed fluoride concentration according to the legislation and the remaining salt samples (43\%) showed concentration lower than the minimum recommended.

Additionally, it was observed variability of the mean fluoride concentration within the same brand (Tab 2). As described in the results item, all the seven packages of salt analyzed were produced by the same manufacturer but were products of 4 brands (Table 1). Moreover, three of the brands analyzed (PuraSal yodada cocina, Emsal yodada cocina and Sal extra refinada-Marina) were purchased in duplicate but from different batches (Tab 1). Table 2 shows that one sample from each brand presented adequate fluoride concentration, but its duplicate did not. Considering that all salts were produced by the same manufacturer and probably by the same process of fluoride addition, the findings suggest that the program of quality control of fluoride concentration during salt production is deficient.

Moreover, when the data of mean fluoride concentration in the salts (Table 2) are confronted with the data of fluoride concentration in the fractions of salts sieved (Table 3), other problems are noticed. Thus, although the mean fluoride concentration found in salts code 2, 4 and 6 (table 2) are according the Peruvian legislation, they were not the most homogeneous (Table 3) compared with salts batches 1, 3 and 5. Fluoride concentration in the fractions of salts 2,4 and 6 ranged respectively from 116.2 to 
1449.7 (12-fold), 72.0 to 420.9 (6-fold) and 120.9 to 380.2 (3-fold), while in salts 1,3 and 5 ranged from 98.6 to 332.4 (3-fold), 115.1 to 167.5 (1.4-fold) and 164.6 to 221.3 (1.3-fold). Therefore, for example, when people use a small amount of salts code 2 , 4 or 6 in a salad than a larger amount to cook foods, they were subjected to greater variability of fluoride ingestion.

Although the sampling of salts analyzed in our study was limited to only 7 packages of salt, we compared our findings (Table 2) with reports from Peru and other countries, where the program of salt fluoridation was implemented ${ }^{10-15}$. Sunohara ${ }^{15}$ analyzed in 2005 ten brands of Peruvian salts. Fluoride was found in only one brand (EMSAL Yodada de Mesa) but fluoride concentration was below the legislation (152 ppm F). In this same brand (Table 2, code 7), we found $237.2 \mathrm{ppm}$ F. This difference found in the same brand shows deficiency of a program of quality control of fluoride concentration during the production of salt.

The results that we found in Peruvian salts (Table 2) are similar to findings for 75 Mexican salts analyzed in 2002 and 2003 because $50 \%$ of the samples were in agreement with the local legislation (200-250 mg F/ $/ \mathrm{kg})^{10}$. However, other analyses conducted in Mexican salts have found worst results. Analyses made in $1995^{11}$ and in $2008^{12}$ showed respectively that only 1 and $7 \%$ of the salt samples presented fluoride concentration in accordance with the local legislation.

Regarding labeling, all the Peruvian salt brands selected are in agreement with the Peruvian norm of salt for human consumption ${ }^{17}$ in terms of the declaration of the fluoride concentration in $\mathrm{mg} / \mathrm{kg}$ of salt, method used for fluoride addition, sanitary registration number, batch, date of production and expiration. The discrepancy between the mean fluoride concentration found (Table 2) and that declared by the manufacturer (Table 1) on the label of samples code 1, 3 and 5 is due to the deficiency of quality control of fluoride concentration during salt production, as described before.

Although the present pilot study was limited to samples of salts found in Lima, the impact of fluoride concentration found (Table 2) for the Peruvian population, considering the anticaries benefits and the risks of dental fluorosis of the salt fluoridation program implemented in Peru may be discussed. People who use salt brands 2, 4, 6 and 7 would have the maximum anticaries effect but who use salts 1,3 and 5 would be less protected. However, dental caries is a chronic disease and the effect of fluoride on caries is local, not systemic ${ }^{23}$. Therefore, the time of maintenance of an effective fluoride concentration in the mouth to interfere with the caries process should be considered than "optimal" concentration for short time. Also, it is not known whether salts with concentration of around $150 \mathrm{mg} \mathrm{F} / \mathrm{kg}$ (Tab 2) would be less effective in terms of caries prevention regarding salts with concentration of 200-250 mg F/ kg.

Concerning dental fluorosis, the risk is not increased because none of the salt samples presented mean fluoride concentration above the established range (Table 2). However, when the salt was fractioned it was found in the sample code 2 a fraction with 1449.7 $\mathrm{mg} \mathrm{F} / \mathrm{kg}$ (Tab 3). Although this concentration is around 6-fold the upper limit, there is a few concern because it was found in very small salt particle $(0.420-0.59 \mathrm{~mm})$. A small particle could be used by chance for example to add salt to a tomato slice but not to cook, when larger amount of salt is used. Therefore, assuming that a $20 \mathrm{~kg}$ child added 
$0.1 \mathrm{~g}$ of salt with concentration of $1449.7 \mathrm{mg} \mathrm{F} / \mathrm{kg}$ to a tomato slice, he would intake $0.15 \mathrm{mg}$ of fluoride. Thus, the child would be subjected to the dose of $0.0075 \mathrm{mg} \mathrm{F} / \mathrm{kg}$ of body weight, which is 10 times lower the upper limit dose for unacceptable risks of fluorosis ${ }^{24}$. Indeed, Peruvian children are not exposed to dose of risks of fluorosis from foods cooked with fluoridated saltt2 ${ }^{2}$. In addition, dental fluorosis is a chronic disease and the time of duration of an "optimun" dose is more relevant than sporadic higher dose. However, this discussion about fluorosis risks of the Peruvian fluoridated salt program is not considering the effect of fluoridated salt for people living in areas containing natural fluoride. In fact, the Peruvian regulation set that "the population who is exposed to water containing natural fluoride at concentration of $0.7 \mathrm{ppm}$ or greater does not need consume fluoridated salt". However, it does not establish any mechanism to avoid that fluoridated salt is market in these areas.

The overall findings of this pilot study about fluoride concentration in salts marketed in Lima, Peru, and the publication cited $^{15}$, alert about the need to improve the monitoring of the fluoride concentration in salt that is responsibility of manufacturers and governmental entities. It is reasonable to think that the balance between the anticaries potential and low risk of fluorosis requires an adequate concentration of fluoride in salt.

Based on this pilot finding, we concluded that the manufacturing and surveillance system of fluoridated salt in Peru should be reinforced.

\section{ACKNOWLEDGMENTS}

A preliminary report of this study was presented at the 92nd IADR General Session and Exhibition, 2014.

\section{REFERENCES}

1. Petersen PE. The World Oral Health Report 2003: continuous improvement of oral health in the $21 \mathrm{st}$ century - the approach of the WHO Global Oral Health Programme. Community Dent Oral Epidemiol. 2003 Dec;31 Suppl 1:3-23

2. Petersen PE, Lennon M. Effective use of fluorides for the prevention of dental caries in the $21 \mathrm{st}$ century: the WHO approach. Community Dent Oral Epidemiol. 2004 Oct;32(5):319-21.

3. Jones S, Burt BA, Petersen PE, Lennon MA. The effective use of fluorides in public health. Bull World Health Organ. 2005 Sep;83(9):670-6

4. Marthaler TM, Petersen PE. Salt fluoridation - an alternative in automatic prevention of dental caries. Int Dent J. 2005 Dec;55(6):351-8.

5. O'Mullane DM, Baez RJ, Jones S, Lennon MA, Petersen PE, Rugg-Gunn AJ. Fluoride and Oral Health Community Dent Health. 2016 Jun;33(2):69-99.

6. Gillespie GM, Baez R. Development of salt fluoridation in the Americas. Schweiz Monatsschr Zahnmed. 2005;115(8):663-9

7. Pollick HF. Salt fluoridation: a review. J Calif Dent Assoc. 2013 Jun;41(6):395-7, 400-4

8. Sosa Rosales M de la C, García Melian M, Gómez A, González I, Mojáiber de la Peña A. [Surveillance System of the program of salt fluoridation of human consumption in Cuba]. Rev Cubana Salud Pública. 2004 Sep-Dic [cited 2017 Sep 29]; 30(4). Available from: http://scielo.sld.cu/scielo. php?script=sci_arttext\&pid=S0864-34662004000400011. Spanish. 
9. Girón Álvarez BE, Márquez Hernández RV, Sermeño Camacho KJ. [Presence and concentration of fluoride in salt brands marketed in El Salvador] Crea Cienc. 2005 [cited 2017 Sep 29];5(2)5-9. Available from: http://dsuees.uees.edu.sv/xmlui/handle/20.500.11885/104. Spanish.

10. Martínez-Mier EA, Soto Rojas AE, Buckley CM, Stookey GK, Zero DT, Margineda J. [Evaluation of fluoride content in fluoridated table salt]. Salud Publica Mex. 2004 May-Jun;46(3):197-8. Spanish.

11. Maupomé Carvantes G, Lanchero Jaramillo D, Andrade Delgado LC, Juárez Reyes PL, Pérez López R, Navarro Sánchez W, et al. [Fluoride contained in salt for human consumption distributed in Mexico City] Bol Of Sanit Panam. 1995 Sep;119(3):195-201. Spanish

12. Hernández-Guerrero JC, De La Fuente-Hernández J, Jiménez MD, Ledesma-Montes C, CastañedaCastaneira E, Molina-Frechero N. Fluoride content in table salt distributed in Mexico City, Mexico. J Public Health Dent. 2008;68(4):242-5. Spanish

13. Franco AM, Saldarriaga A, Gonzalez MC, Martignon S, Arbelaez MI, Ocampo A. [Fluoride concetration in kitchen salt in four Colombian cities] Revista CES Odontología Vol. 16. 2003. p. 21-6. Spanish

14. Tovar Valencia S, Misnaza Castrillon S. Perspectiva del uso del flúor vs caries y fluorosis dental [Technical document on the internet] Colombia: Minsalud; 2016 [cited 2017 Sep 29] Available from: http://www.minsalud.gov.co/sites/rid/Lists/Bibliotecadigital/RIDE//VS/PP/ENT/ perspectiva-uso-fluor.pdf

15. Sunohara ASA. [Mapping of fluoridated salt in markets of the province of Trujillo using the geographic information system]. Rev Estomatol Hered. 2006;16(1):5-8. Spanish

16. Ministerio de Salud Perú [homepage]. Lima: Minsa Resolución ministerial № 0131-85-SA-DVM; 1985 [cited 2017 Set 29] Available from: ftp://ftp2.minsa.gob.pe/descargas/Prevencion_salud/salud bucal/rm0131-85-sa-dvm.pdf

17. Ministerio de Salud Perú [homepage] Lima: Minsa Norma técnica Peruana Sal para Consumo Humano. 2006 [cited 2017 Set 29] Available from: ftp://minsa.gob.pe/normaslegales/2006

18. Cury JA, Guimarães LO, Moreira BH [Fluoridation of cooking salt: a method for familiar use]. Rev Ass Paul Cirurg Dent. 1983;37(5):452-455. Portuguese

19. Martínez-Mier EA, Soto-Rojas AE, Buckley CM, Margineda J, Zero DT. Evaluation of the direct and diffusion methods for the determination of fluoride content in table salt. Community Dent Health. 2009 Dec;26(4):204-10

20. Martínez-Mier EA, Cury JA, Heilman JR, Katz BP, Levy SM, Li Y. Development of gold standard ionselective electrode-based methods for fluoride analysis. Caries Res. 2011;45(1):3-12

21. European Salt Producers Association. Sodium Chloride - Analytical Standard Determination of Fluorides Potentiometric method [Technical document on the internet]. European Salt Producers Association 2005 [cited 2017 Sep 29]. Available from:http://eusalt.com/sites/www.eusalt.com/files/ pagedocuments/EuSalt\%20AS0172005\%20Fluorides\%20\%20Potentiometric\%20Method.pdf

22. Campbell AD. Determination of fluoride in various matrices. Pure Appl Chem. 1987;59(5):695-702

23. Cury JA, Tenuta LMA. How to maintain a cariostatic fluoride concentration in the oral environment Adv Dent Res. 2008 Jul 1;20(1):13-6

24. Burt BA. The Changing Patterns of Systemic Fluoride Intake. J Dent Res. 1992 May 1;71(5):1228-37. Review.

25. Rodrigues MH, Leite AL, Arana A, Villena RS, Forte FD, Sampaio FC, Buzalaf MA. Dietary fluoride intake by children receiving different sources of systemic fluoride. J Dent Res. 2009 Feb;88(2):142-5. 